\title{
DYNAMICS OF CROPPING PATTERN IN ANDHRA PRADESH, INDIA
}

\author{
SAGINA VENKATESH ${ }^{1} \&$ CHANDRA SEN ${ }^{2}$ \\ ${ }^{1}$ Student, Department of Agricultural Economics, I.A.S., Banaras Hindu University, \\ Varanasi, Uttar Pradesh, India \\ ${ }^{2}$ Professor, Department of Agricultural Economics, I.A.S., Banaras Hindu University, \\ Varanasi, Uttar Pradesh, India
}

\begin{abstract}
Agriculture sector is the backbone of the country's development as most of the population still dependent on agriculture. The crop acreages also have been found to be changing in specific areas due to various factors such as season, climate and rainfall. Shift in cropping pattern by the farmers such as from the non-profitable crops to profitable or remunerative crops which have more productivity and high prices in the market. This change in cropping pattern is mainly to minimize the risk to cover crop profitability. The cropping pattern of Andhra Pradesh has been shifted to major crops like Paddy, Cotton, Maize, Sugarcane etc. The area under food crops has been decreased by $2.99 \%$ but the area under non-food crops found to be increased by $2.11 \%$ from 2015-16 to 2016-17 which indicates the area under cotton, tobacco etc. has been found to be increasing in Andhra Pradesh state. The total gross cropped area of the state was found to be decreasing by $0.37 \%$ but the total production and productivity have been found to increase by $13.37 \%$ and $33.34 \%$ from 2003-04 to 2014-15.
\end{abstract}

KEYWORDS: Agriculture, Cropping Pattern, Area, Production \& Productivity

Received: May 11, 2018; Accepted: Jun 01, 2018; Published: Jul 05, 2018; Paper Id.: IJASRAUG20182

\section{INTRODUCTION}

Cropping pattern is a dynamic concept because no cropping pattern can be said to be ideal for all times to a particular region. It changes in space and time with a view to meet requirements and is governed largely by the physical as well as cultural and technological factors. The change in cropping pattern in particular span of time clearly indicates the changes that have taken place in the agricultural development. These changes are brought about by socioeconomic influence. "In most of the situations, the physical environment reduces the choice of certain crops altogether or by reducing their level (Morgan, W.B. and Munton R.J.C. 1971). Change in cropping pattern is occurring as a strategy to minimize risk to cover crop profitability where the immediate goal is not to make a profit but to stabilize income from crop sequence adopted in a year. The overall deciding factors regarding the total cropping pattern of the cultivators' holding as a whole also included aspects as the availability of manure and irrigation facilities and the need of the household for food and fodder.

\section{Factors that Affects the Cropping Pattern in India}

The cropping pattern is highly influenced by climatic, personal, social, cultural and economic factors of the farmers. They are as follows: i) Size of the Land Holding ii) Literacy iii) Disease and pest iv) Ecological Suitability v) Moisture Availability vi) Financial Stability.

The present study was undertaken to probe into the various aspects of the cropping pattern of Andhra 
Pradesh with special reference to its' dynamics and factors associated as area and yield affects the production in existing cropping pattern. The specific objective of the present study is to find out the absolute and relative change in cropping pattern of Andhra Pradesh state.

\section{RESEARCH METHODOLOGY}

The major crops in the region were selected on the basis of percentage share of crops' acreage in cropping pattern to total kharif and rabi area of the region. For this purpose, secondary data for the period of 12 years available in other sources were utilized. In order to get a comprehensive picture of major crops area of Andhra Pradesh, the time series data for the period of 12 years from 2003-04 to 2014-15 was collected. In order to minimize the irregular fluctuation in time series data, the three years average (triennium) was worked out where ever it is required. The crops that are selected in the present study are Paddy, Sugarcane, Cotton, Groundnut, Maize, and Blackgram.

\section{ANALYTICAL TOOLS}

\section{Arithmetic Mean}

The mean was worked out using the time series data on area, production and productivity of major crops of Andhra Pradesh. The method is defined as:

$$
\bar{X}_{t}=\sum_{i=1}^{n} X_{i t} / n
$$

Where,

$$
\begin{aligned}
& \overline{\mathrm{X}}_{\mathrm{t}}=\text { Arithmetic mean for " } \mathrm{t} \text { " period } \\
& \mathrm{X}_{\mathrm{it}}=\text { Value of the item } \\
& \mathrm{n}=\text { Number of years }
\end{aligned}
$$

\section{RESULTS AND DISCUSSIONS}

In the present study, time series data of important crops variables (viz. area, production and productivity) have been synthesized by statistical tool viz. arithmetic mean.

\section{Cropping Pattern of Andhra Pradesh}

The data of the study shows that the gross cropped area of the Andhra Pradesh in the base year found to 80.15 lakh hectares. The cropping pattern of the state is mainly comprised of Paddy, Groundnut, Cotton and other crops in kharif season covering 53.49 lakh hectares i.e. $66.73 \%$ of gross cropped area (triennium average of 2003-04 to 2005-06 respectively) and Paddy, Maize, Blackgram and other crops in rabi season covering 26.66 lakh hectares i.e. $33.26 \%$ of total gross cropped area (triennium average of 2003-04 to 2005-06 respectively). The proportionate acreage covered by individual crops is presented in table 1: 
Table 1: Cropping Pattern of Andhra Pradesh in the Base and Current Year and Acreage Shift among Crops over a Period of Time. (Area in Lakh Hectares)

\begin{tabular}{|c|c|c|c|c|c|}
\hline \multirow[t]{2}{*}{ Crop } & \multicolumn{2}{|c|}{$\begin{array}{c}\text { Area (Triennium } \\
\text { Average) }\end{array}$} & \multicolumn{2}{|c|}{$\begin{array}{c}\text { Percentage to Respective } \\
\text { Gross Cropped Area } \\
\text { in the Year }\end{array}$} & \multirow[t]{2}{*}{$\begin{array}{c}\text { Difference between } \\
\text { Two Periods of } \\
\text { Time }\end{array}$} \\
\hline & $\begin{array}{c}\text { 2003-04 } \\
\text { To } \\
2005-06 \\
\end{array}$ & $\begin{array}{c}\text { 2012-13 } \\
\text { To } \\
\text { 2014-15 } \\
\end{array}$ & $\begin{array}{c}\text { 2003-04 } \\
\text { To } \\
2005-06 \\
\end{array}$ & $\begin{array}{c}\text { 2012-13 } \\
\text { To } \\
2014-15 \\
\end{array}$ & \\
\hline Paddy (kharif) & 15.09 & 16.23 & 18.82 & 20.32 & +7.55 \\
\hline Sugarcane & 1.69 & 1.49 & 2.10 & 1.86 & -11.83 \\
\hline Groundnut & 14.18 & 9.77 & 17.69 & 12.23 & -31.10 \\
\hline Cotton & 3.56 & 6.89 & 4.44 & 8.62 & +93.53 \\
\hline $\begin{array}{l}\text { Other kharif } \\
\text { crops }\end{array}$ & 18.97 & 17.82 & 23.66 & 22.31 & -6.06 \\
\hline $\begin{array}{l}\text { Total Kharif } \\
\text { Crops }\end{array}$ & 53.49 & 52.20 & 66.73 & 65.37 & -2.41 \\
\hline Paddy (rabi) & 7.26 & 7.71 & 9.05 & 9.65 & +5.83 \\
\hline Maize & 0.77 & 2.21 & 0.96 & 2.76 & +187.01 \\
\hline Blackgram & 3.30 & 3.05 & 4.11 & 3.81 & -7.57 \\
\hline $\begin{array}{l}\text { Other rabi } \\
\text { crops }\end{array}$ & 15.33 & 14.68 & 19.12 & 18.38 & -4.24 \\
\hline $\begin{array}{l}\text { Total Rabi } \\
\text { Crops }\end{array}$ & 26.66 & 27.65 & 33.26 & 34.62 & +3.71 \\
\hline $\begin{array}{l}\text { Gross } \\
\text { Cropped } \\
\text { Area } \\
\end{array}$ & 80.15 & 79.85 & 100 & 100 & -0.37 \\
\hline
\end{tabular}

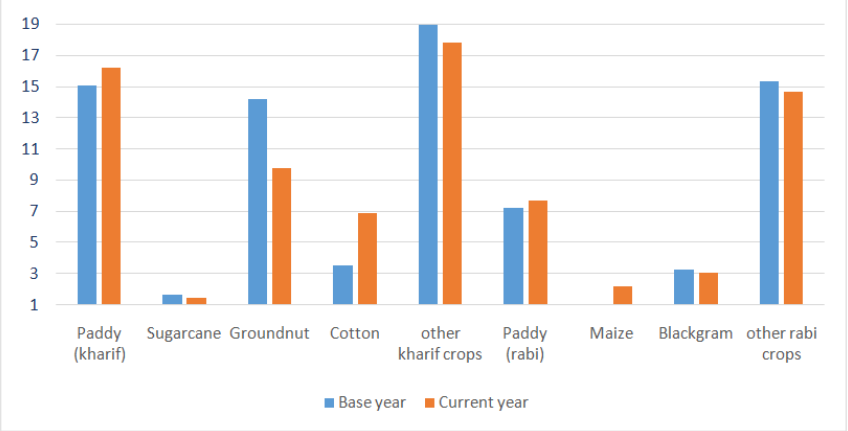

Figure 1: Cropping Pattern of State (Base and Current year) "Area in Lakh Hectares"

The data in table 1 revealed that entire cropped area of the state is found to be dominated by kharif crops with 53.49 lakh hectares i.e. $66.73 \%$ to the gross cropped area in a base year. Area under rabi crops was 26.66 lakh hectares which are $33.26 \%$ of the gross cropped area. Paddy is dominated and accounted by $18.82 \%$ area to gross cropped area. Paddy occupied the maximum area in kharif as well as in rabi season, Blackgram $(4.11 \%)$ and Maize $(0.96 \%)$ of the gross cropped area in rabi season respectively. After laps of 12 years since 2003-04 to 2014-15, cropping pattern of Andhra Pradesh revealed some definite changes as shown in table 1. In current year of study (Triennium average 2012-13 to 201415), the area under gross cropped area was decreased since base year by $0.37 \%$. The crops whose area increased over a period of time was Paddy (7.55\% in kharif and 5.83\% in rabi), Cotton (93.53\%) and Maize (187.01\%) respectively. The area under Sugarcane (11.83\%), Groundnut (31.10\%) and Blackgram (7.57\%) and other rabi crops by (4.24\%) shown considerably decline. Thus, it is concluded that the Maize area is found the highest and increased by $187.01 \%$ over a period of time followed by Cotton $(93.53 \%)$ and Paddy (7.55\%). Crops whose area found to decline since base year are 
Groundnut (31.10\%), other kharif crops $(2.41 \%)$ and other rabi crops $(4.24 \%)$ respectively.

\section{Production Variability in Andhra Pradesh State}

The total production of all crops in the Andhra Pradesh during the base year found to 285.7 lakh tones. It increased to 323.91 lakh tonnes in the current year or an increase of $13.37 \%$ over the base year. Production of Paddy, Cotton and Maize found to increase by $11.55,154.75$ and $217.27 \%$ respectively. However, the production of Sugarcane and Groundnut crops found to decline. Thus, in detail study reveals that the downfall of total production in case of Groundnut crop was $40.09 \%$ followed by Sugarcane crop with $9.21 \%$ respectively in the current year as from the base year.

Table 2: Production Pattern of Crops in Andhra Pradesh State (Base and Current Year) and Change in Production among Crops over a Period of Time.(Production in Lakh Tonnes)

\begin{tabular}{|c|c|c|c|c|c|}
\hline \multirow[t]{2}{*}{ Crop } & \multicolumn{2}{|c|}{$\begin{array}{c}\text { Production } \\
\text { (Triennium Average) }\end{array}$} & \multicolumn{2}{|c|}{$\begin{array}{c}\text { Percentage to Total } \\
\text { Production }\end{array}$} & \multirow[t]{2}{*}{$\begin{array}{l}\text { Difference Between } \\
\text { Two Periods of Time }\end{array}$} \\
\hline & $\begin{array}{c}\text { 2003-04 } \\
\text { to } \\
2005-06\end{array}$ & $\begin{array}{c}\text { 2012-13 } \\
\text { to } \\
2014-15\end{array}$ & $\begin{array}{c}\text { 2003-04 } \\
\text { to } \\
2005-06\end{array}$ & $\begin{array}{c}2012-13 \\
\text { to } \\
2014-15\end{array}$ & \\
\hline Paddy (kharif) & 60.50 & 67.49 & 21.17 & 20.83 & +11.55 \\
\hline Sugarcane & 124.84 & 113.34 & 43.69 & 34.99 & -9.21 \\
\hline Groundnut & 8.63 & 5.17 & 3.02 & 1.59 & -40.09 \\
\hline Cotton & 8.42 & 21.45 & 2.94 & 6.62 & +154.75 \\
\hline Other kharif crops & 18.59 & 31.13 & 6.50 & 9.61 & +67.45 \\
\hline Paddy (rabi) & 43.17 & 49.06 & 15.11 & 15.14 & +13.64 \\
\hline Maize & 5.21 & 16.53 & 1.82 & 5.10 & +217.27 \\
\hline Blackgram & 1.83 & 2.60 & 0.64 & 0.80 & +42.07 \\
\hline Other rabi crops & 14.51 & 17.14 & 5.07 & 5.29 & +18.12 \\
\hline Total Production & 285.7 & 323.91 & 100 & 100 & +13.37 \\
\hline
\end{tabular}

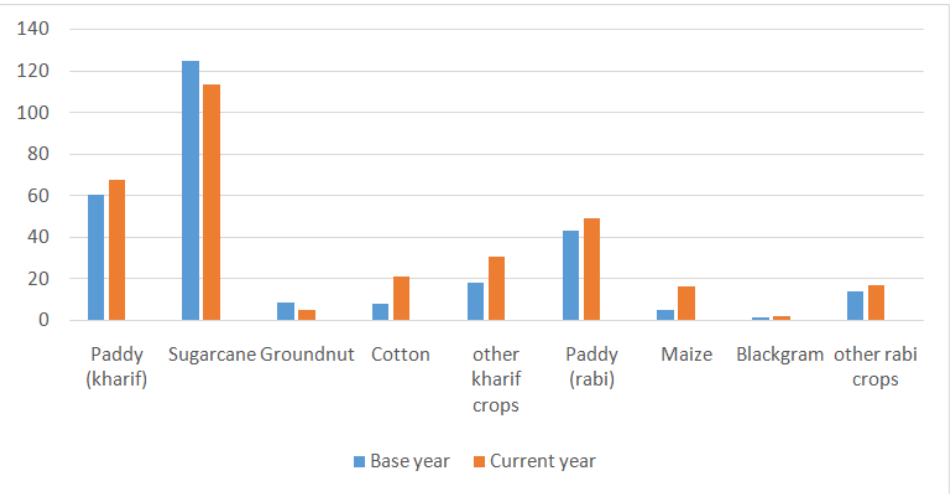

Figure 2: Production Pattern of State (base and Current Year) "Production in Lakh Tonnes"

\section{Yield Variability in Andhra Pradesh}

The introduction of technology and modern inputs with an improved package of practices in agriculture bound to make an overall increase in productivity per unit of area. This is true for the area under study that the productivity found to increase in the current year $(33.34 \%)$ from base year. Table 3.The data on productivity shows increasing behavior in all the crops except the Groundnut crop. Blackgram has highest yield variability $(54.72 \%$ increase over the base year) followed by Cotton (29.52\%), Paddy (3.53\%), Sugarcane (2.82\%), other kharif crops (78.01\%) and other rabi crops 
(56.84\%) increased over base year respectively. Thus it is concluded that only Groundnut crop shows downfall in productivity $(13.37 \%)$ over the base year.

Table 3: Productivity Pattern of Crops in Andhra Pradesh State (Base and Current Year) and Change in Productivity among Crops over a Period of TIme. (Kg./hact.)

\begin{tabular}{|c|c|c|c|c|c|}
\hline \multirow[t]{2}{*}{ Crop } & \multicolumn{2}{|c|}{$\begin{array}{c}\text { Productivity } \\
\text { (Triennium Average) }\end{array}$} & \multicolumn{2}{|c|}{$\begin{array}{l}\text { Percentage to Total } \\
\text { Productivity }\end{array}$} & \multirow[t]{2}{*}{$\begin{array}{c}\text { Difference Between } \\
\text { Two Periods of } \\
\text { Time } \\
\end{array}$} \\
\hline & $\begin{array}{c}\text { 2003-04 } \\
\text { To } \\
2005-06 \\
\end{array}$ & $\begin{array}{c}\text { 2012-13 } \\
\text { To } \\
2014-15 \\
\end{array}$ & $\begin{array}{c}2003-04 \\
\text { To } \\
2005-06 \\
\end{array}$ & $\begin{array}{c}\text { 2012-13 } \\
\text { To } \\
2014-15\end{array}$ & \\
\hline Paddy (kharif) & 4016 & 4158 & 21.37 & 16.59 & +3.53 \\
\hline Sugarcane & 73832 & 75920 & 392.95 & 303.01 & +2.82 \\
\hline Groundnut & 598 & 518 & 3.18 & 2.06 & -13.37 \\
\hline Cotton & 403 & 522 & 2.14 & 2.08 & +29.52 \\
\hline $\begin{array}{l}\text { Other kharif } \\
\text { crops }\end{array}$ & 42206 & 75133 & 224.63 & 299.87 & +78.01 \\
\hline Paddy (rabi) & 5948 & 6358 & 31.65 & 25.37 & +6.89 \\
\hline Maize & 6767 & 7483 & 36.01 & 29.86 & +10.58 \\
\hline Blackgram & 550 & 851 & 2.92 & 3.39 & +54.72 \\
\hline Other rabi crops & 34786 & 54560 & 185.14 & 217.76 & +56.84 \\
\hline $\begin{array}{c}\text { Total } \\
\text { Productivity }\end{array}$ & 18789 & 25055 & 100 & 100 & +33.34 \\
\hline
\end{tabular}

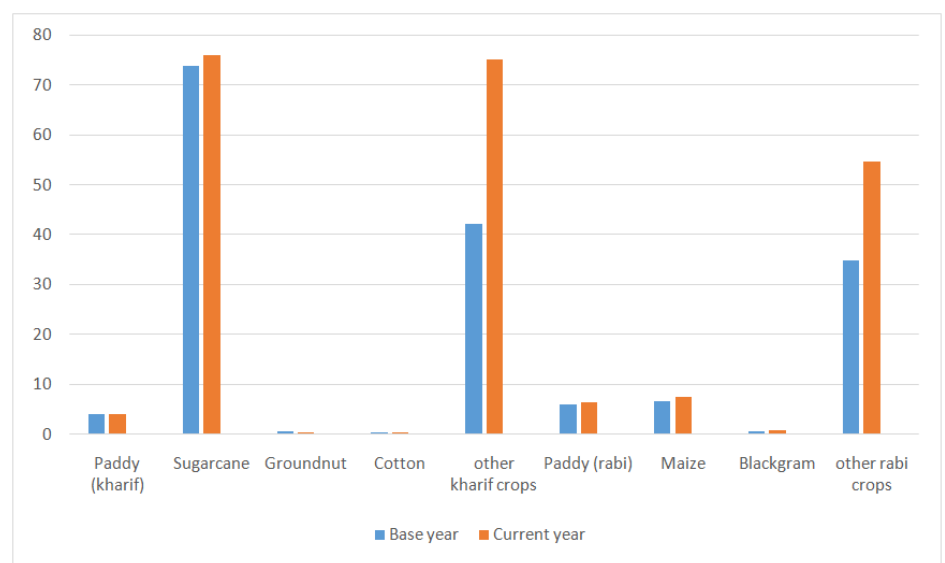

Figure 3: Productivity Pattern of State (Base and Current Year) "Productivity in Tonnes/Hectare"

\section{Comparison of Area, Production and Productivity Variabilities}

Table 4 Illustrates area, production and productivity variability as a comparative picture among the crops have been studied in Andhra Pradesh during the period of 12 years. It can be noted from the table that in case of Paddy and Cotton area, production and productivity found to increase tremendously. Sugarcane area and production shows considerable decline but the productivity per unit of the area given encouraging result of increased $2.82 \%$ over the base year. In rabi season, Paddy and Maize show increased in area, production and productivity over base year respectively. The area of Blackgram and other rabi crops found to decrease but production and productivity found to be positive i.e. increase respectively over the base year. 
Table 4: Comparative Variabilities of Area, Production and Productivity of Major Crops in Andhra Pradesh State

\begin{tabular}{|l|c|c|c|l|}
\hline & \multicolumn{2}{|c|}{$\begin{array}{c}\text { Percentage Variabilities over a Period } \\
\text { of Time (2003-04 to 2014-15) }\end{array}$} & \\
\hline \multicolumn{1}{|c|}{ Crop } & Area & Production & Productivity & \multicolumn{1}{|c|}{ Remarks } \\
\hline Paddy (kharif) & +7.55 & +11.55 & +3.53 & $\begin{array}{l}\text { Area, Production and Productivity found to } \\
\text { increase }\end{array}$ \\
\hline Sugarcane & -11.83 & -9.21 & +2.82 & $\begin{array}{l}\text { Area and production decrease but the } \\
\text { productivity found to increase }\end{array}$ \\
\hline Groundnut & -31.10 & -40.09 & -13.37 & $\begin{array}{l}\text { Area, production and productivity found to } \\
\text { decrease }\end{array}$ \\
\hline Cotton & +93.53 & +154.75 & +29.52 & $\begin{array}{l}\text { Area, production and productivity found to } \\
\text { increase }\end{array}$ \\
\hline $\begin{array}{l}\text { Other kharif } \\
\text { crops }\end{array}$ & -6.06 & +67.45 & +78.01 & $\begin{array}{l}\text { Area decrease but production } \\
\text { productivity found to increase }\end{array}$ \\
\hline Paddy (rabi) & +5.83 & +13.64 & +6.89 & $\begin{array}{l}\text { Area, production and productivity found to } \\
\text { increase }\end{array}$ \\
\hline Maize & +187.01 & +217.27 & +10.58 & $\begin{array}{l}\text { Area, production and productivity found to } \\
\text { increase }\end{array}$ \\
\hline Blackgram & -7.57 & +42.07 & +54.72 & $\begin{array}{l}\text { Area decrease but production } \\
\text { productivity found to increase }\end{array}$ \\
\hline $\begin{array}{l}\text { Other rabi } \\
\text { crops }\end{array}$ & -4.24 & +18.12 & +56.84 & $\begin{array}{l}\text { Area decrease but production } \\
\text { productivity found to increase }\end{array}$ \\
\hline \multicolumn{1}{|c|}{ Total Crop } & $\mathbf{- 0 . 3 7}$ & $+\mathbf{1 3 . 3 7}$ & $+\mathbf{3 3 . 3 4}$ & $\begin{array}{l}\text { Area Decrease but Production and } \\
\text { Productivity Found to Increase }\end{array}$ \\
\hline
\end{tabular}

\section{Relative Change in Production Component}

The area and productivity are the main components of total production and therefore, the relative change in the area, production and productivity of major crops for the period of 12 years were estimated in the study. The average triennium data of the relative change in area, production and productivity of major crops growing in Andhra Pradesh state are shown in table below.

Table 5: Triennium Average and their Relative Change of Area under Different Major Crops of Andhra Pradesh State of the Base Year and Current Year (2003-06 and 2012-15).

\begin{tabular}{|l|c|c|}
\hline \multicolumn{1}{|c|}{ Crop / Year } & 2003-04 to 2005-06 & 2012-13 to 2014-15 \\
\hline \multirow{2}{*}{ Paddy (kharif) } & 15.09 & 16.23 \\
& $(100)$ & $(107.55)$ \\
\hline \multirow{2}{*}{ Sugarcane } & 1.69 & 1.49 \\
& $(100)$ & $(88.17)$ \\
\hline \multirow{2}{*}{ Groundnut } & 14.18 & 9.77 \\
& $(100)$ & $(68.9)$ \\
\hline \multirow{2}{*}{ Cotton } & 3.56 & 6.89 \\
& $(100)$ & $(193.53)$ \\
\hline \multirow{2}{*}{ Other kharif crops } & 18.97 & 17.82 \\
& $(100)$ & $(93.94)$ \\
\hline \multirow{2}{*}{ Paddy (rabi) } & 7.26 & 7.71 \\
& $(100)$ & $(105.83)$ \\
\multirow{2}{*}{ Maize } & 0.77 & $(287.01)$ \\
\hline \multirow{2}{*}{ Blackgram } & $(100)$ & 3.05 \\
& 3.30 & $(92.43)$ \\
\hline \multirow{2}{*}{ Other rabi crops } & $(100)$ & $(95.76)$ \\
\hline
\end{tabular}




\begin{tabular}{|c|c|c|}
\hline \multicolumn{3}{|c|}{ Table 5: Contd., } \\
\hline \multirow{2}{*}{ Total Area } & $\mathbf{8 0 . 1 5}$ & $\mathbf{7 9 . 8 5}$ \\
& $(100)$ & $(99.63)$ \\
\hline
\end{tabular}

Note: Area in lakh hectares. (Figure in parenthesis shows relative change over base year)

The data of the relative change in acreage of overall crops in Andhra Pradesh found to decrease. It is decreased by $0.37 \%$ over the base year to current year. The relative change in acreage under Paddy, Cotton and Maize was found to increase. On the other hand, the relative change in acreage of Sugarcane, Groundnut, Blackgram, other kharif and rabi crops was found to decrease.

Table 6: Triennium Average and their Relative Change of Production under Different Major Crops of Andhra Pradesh State of the base Year and Current Year (2003-06 and 2012-15)

\begin{tabular}{|c|c|c|}
\hline Crop / Year & $2003-04$ to $2005-06$ & $2012-13$ to $2014-15$ \\
\hline Paddy (kharif) & $\begin{array}{l}60.50 \\
(100)\end{array}$ & $\begin{array}{c}67.49 \\
(111.55)\end{array}$ \\
\hline Sugarcane & $\begin{array}{c}124.84 \\
(100)\end{array}$ & $\begin{array}{c}113.34 \\
(90.79)\end{array}$ \\
\hline Groundnut & $\begin{array}{c}8.63 \\
(100)\end{array}$ & $\begin{array}{c}5.17 \\
(59.91)\end{array}$ \\
\hline Cotton & $\begin{array}{c}8.42 \\
(100)\end{array}$ & $\begin{array}{c}21.45 \\
(254.75)\end{array}$ \\
\hline Other kharif crops & $\begin{array}{l}18.59 \\
(100)\end{array}$ & $\begin{array}{c}31.13 \\
(167.45)\end{array}$ \\
\hline Paddy (rabi) & $\begin{array}{l}43.17 \\
(100)\end{array}$ & $\begin{array}{c}49.06 \\
(113.64)\end{array}$ \\
\hline Maize & $\begin{array}{c}5.21 \\
(100)\end{array}$ & $\begin{array}{c}16.53 \\
(317.27)\end{array}$ \\
\hline Blackgram & $\begin{array}{c}1.83 \\
(100) \\
\end{array}$ & $\begin{array}{c}2.60 \\
(142.07) \\
\end{array}$ \\
\hline Other rabi crops & $\begin{array}{l}14.51 \\
(100)\end{array}$ & $\begin{array}{c}17.14 \\
(118.12)\end{array}$ \\
\hline Total Production & $\begin{array}{l}285.7 \\
(100)\end{array}$ & $\begin{array}{c}323.91 \\
(113.37)\end{array}$ \\
\hline
\end{tabular}

Note: Production in lakh tonnes. (Figure in parenthesis shows relative change over base year)

The relative change in production of Paddy, Cotton, Maize, Blackgram, other kharif and rabi crops found to increase in Andhra Pradesh state. On the other hand, the relative change in production of Sugarcane, other Groundnut crops found to be negative during the period of study. The overall relative change among all the crops as whole in Andhra Pradesh state was found to increase by $13.37 \%$ over the base year.

Table 7: Triennium Average and Their Relative Change of Productivity under Different Major Crops of Andhra Pradesh State of Base Year and Current Year (2003-06 and 2012-15)

\begin{tabular}{|l|c|c|}
\hline \multicolumn{1}{|c|}{ Crop / Year } & 2003-04 to 2005-06 & 2012-13 to 2014-15 \\
\hline \multirow{2}{*}{ Paddy (kharif) } & 4016 & 4158 \\
& $(100)$ & $(103.53)$ \\
\hline \multirow{2}{*}{ Sugarcane } & 73832 & 75920 \\
& $(100)$ & $(102.82)$ \\
\hline \multirow{2}{*}{ Groundnut } & 598 & 518 \\
& $(100)$ & $(86.63)$ \\
\hline \multirow{2}{*}{ Cotton } & 403 & 522 \\
& $(100)$ & $(129.52)$ \\
\hline
\end{tabular}




\begin{tabular}{|l|c|c|}
\hline Other kharif crops & $\begin{array}{c}42206 \\
(100)\end{array}$ & $\begin{array}{c}75133 \\
(178.01)\end{array}$ \\
\hline \multirow{2}{*}{ Paddy (rabi) } & 5948 & 6358 \\
$(100)$ & $(106.89)$ \\
\hline \multirow{2}{*}{ Maize } & 6767 & 7483 \\
& $(100)$ & $(110.58)$ \\
\hline \multirow{2}{*}{ Blackgram } & 550 & 851 \\
& $(100)$ & $(154.72)$ \\
\hline \multirow{2}{*}{ Other rabi crops } & 34786 & 54560 \\
& $(100)$ & $(156.84)$ \\
\hline \multirow{2}{*}{ Total Productivity } & $\mathbf{1 8 7 8 9}$ & $\mathbf{2 5 0 5 5}$ \\
& $\mathbf{( 1 0 0 )}$ & $\mathbf{( 1 3 3 . 3 4 )}$ \\
\hline
\end{tabular}

Note: Productivity (Kg/hact.) (Figure in parenthesis shows relative change over base year)

The relative change in productivity of Paddy, Sugarcane, Cotton, Maize and Blackgram was found to increase during the study over to base year. The relative change in productivity of Groundnut crop found to decrease over to the base year. Thus, the overall result in respect of relative dynamic change in an area, production and productivity reveal that in case of other kharif crops and other rabi crops the increase in area and productivity caused for the relative increase in production. The decrease in area under Groundnut and Sugarcane crops shifted towards Cotton and other kharif crops. In concerned with Cotton crop the relative change in an area, production and productivity found to increase during all the years over to base year. The result reveals in case of Maize the increase of area and productivity caused in the increase of the production during all the period of study. The relative productivity of Groundnut found to negative from the base year to current year in Andhra Pradesh state during the span of study.

\section{CONCLUSIONS}

Area of paddy found the highest and increased over a period of time followed by cotton and maize and the area of sugarcane and blackgram found to decline. The study shows that there is a decline in production of groundnut and sugarcane whereas the remaining crops show increasing. Productivity of only groundnut crop found to be declined. The relative change in production and productivity of paddy, cotton, maize and blackgram crops found to be increasing and groundnut crop was found to be decreasing.

\section{REFERENCES}

1. Archana Rai. (2010). Dynamics of cropping pattern in sehore district of Madhya Pradesh. M.Sc.(Ag) Thesis, R.A.K. College of Agriculture, Madhya Pradesh.

2. Bisen, P.K., Sarawgi, A.K. and Sahu R.M. (1993). Growth and variability of major crops in Raisen district, M.P. JNKVV Research Journal, 27(1), 67-70.

3. Choudhry, Anumeha. (2008). Shift in cropping pattern in Vindhyan Plateau of Madhya Pradesh. M.Sc.(Ag) Thesis, College of Agriculture Sehore, Madhya Pradesh.

4. Dayal,R. (1966). Agricultural growth rates and their components. Indian Journal of Agricultural Economics, 21 (4), $227-237$.

5. Al-Satari, Yahya Abdel Rahman. "Intercropping of Atriplex Halimus, Salsola Vermiculata and Barley for Sustainable Feed Production under Rangeland Conditions in Jordan."

6. Dixit,S.P. and Singh.A.K. (1972). Impact of green revolution on Agricultural Production structure, A study of changes in cropping Pattern in U.P. Vol. 27, pp.173.

7. Gautam,A.K. (2015). Cropping pattern in India. 
8. Priyadarshni. Cropping patterns in various regions of India.

9. Mutnuru Srinivasa Rao, Quamrul Hassan, and Naved Ahsan. "Customized Optimal Saline Resistant Cropping Policy: A Case Study."

10. Soni,P.N. (1974). Cropping pattern and crop intensity in various crop intensity in various I.A.D.P districts, Agricultural Situation in India, 483.

11. Tomer,B.S. (1989). Growth of area, production and productivity of important in Haryana. Agricultural Situation in India, 44 (1), 9-13. 
